\title{
Peningkatkan Kemampuan Berpikir Kritis Dan Hasil Belajar Siswa Pada Mata Pelajaran Matematika Materi Jaring-Jaring Bangun Ruang Melalui Penerapan Scientific Approach Kelas V Semester 2 Di SDN 6 Dawuhan Situbondo Tahun Ajaran 2013/2014
}

\author{
Nuris Hidayat ${ }^{1)}$ \\ 1) PGSD FIP Universitas Abdurachman Saleh Situbondo, Indonesia \\ E-mail:Nuris@dr.com
}

\begin{abstract}
Abstrak. Tujuan pembelajaran matematika yaitu menumbuhkan kemampuan berpikir kritis. Proses pembelajaran terdapat beberapa persoalan yang berkembang terutama mengenai mencapai tujuan pembelajaran diantaranya yaitu ketika ada siswa yang mengerjakan soal di papan tulis, ditemukan beberapa kesalahan dalam proses pengerjaan dan jawaban akhir tersebut benar, siswa lain kurang cermat dalam mengamati hanya melihat hasil akhir. Pembelajaran juga masih terpusat pada guru sehingga berpenaruh pada proses berpikir krits dan hasil belajar siswa (nilai ulangan harian) masih rendah. Tempat dan waktu penelitian yaitu di SDN 6 Dawuhan Situbondo. Subjek penelitian adalah siswa kelas V SDN 6 Dawuhan Situbondo berjumlah 35 siswa. Jenis penelitian yang digunakan adalah penelitian tindakan kelas model Kemmis dan Mc Taggart, satu siklus terdiri dari 4 tahapan, yaitu perencanaan, pelaksanaan, observasi, dan refleksi. Teknik pengumpulan data yaitu berupa observasi, wawancara, tes, dan dokumentasi. Sedangkan proses analisis data penelitian ini menggunakan analisis deskriptif persentase aktivitas guru, berpikir kritis dan hasil belajar siswa. Hasil yang diperoleh dalam penelitian ini menunjukkan adanya peningkatan berpikir kritis dan hasil belajar siswa. Pada kemampuan kritis pada tahap siklus 1 sebesar 63\% sebanyak 22 siswa yang tuntas dalam mengerjakan kuis. Pada tahap siklus 2 sebesar $83 \%$ sebanyak 29 siswa yang tuntas dalam mengerjakan kuis. Sedangkan pada hasil belajar tahap pretest sebesar 45\% sebanyak 16 siswa yang tuntas. Pada siklus 1, hasil belajar siswa mengalami peningkatan menjadi $68 \%$ sebanyak 24 siswa yang tuntas belajar dalam ulangan harian. Pada siklus 2 , hasil belajar siswa mengalami peningkatan menjadi 89\% sebanyak 31 siswa yang tuntas. Berdasarkan data tersebut dapat disimpulkan bahwa Scientific Approach dapat meningkatkan berpikir kritis dan hasil belajar siswa materi Jaring-jaring Bangun Ruang kelas V SDN 6 Dawuhan Situbondo.
\end{abstract}

Kata Kunci: Berpikir Kritis, Hasil Belajar, Scientific Approach

\section{PENDAHULUAN}

Matematika merupakan salah satu mata pelajaran wajib untuk sekolah jenjang dasar dan menengah. Hal penting yang merupakan bagian dari tujuan pembelajaran matematika yaitu menumbuhkan kemampuan berpikir kritis. Untuk meningkatkan kemampuan berpikir kritis siswa, hendaknya siswa dibawa ke arah mengamati, menebak, berbuat, mencoba, maupun menjawab pertanyaan mengapa dan kalau mungkin mendebat, karena dengan ini diharapkan dapat menumbuhkan kemampuan berpikir kritis siswa.

Melihat pelaksanaan dalam proses pembelajaran matematika di sekolah SDN 6 Dawuhan Situbondo dirasa belum optima terutama mengenai mencapai tujuan pembelajaran diantaranya yaitu ketika ada siswa yang mengerjakan soal di papan tulis, ditemukan beberapa kesalahan dalam proses pengerjaan dan kebetulan jawaban akhir tersebut benar, siswa lain kurang cermat dalam mengamati hanya melihat hasil akhir. Pembelajaran juga masih terpusat pada guru, sehingga siswa hanya menjadi pendengar yang baik dan pengetahuan yang mereka dapatkan hanyalah pengetahuan yang ditransfer dari seorang guru sehingga konsep yang didapatkan bersifat hayalan saja bukan hasil dari pengalaman yang dimiliki para siswa itu sendiri sehingga berpenaruh pada proses berpikir kritis dan hasil belajar siswa (nilai ulangan harian) masih rendah. Salah satu pendekatan pembelajaran yang bisa menjadi alternatif pemecahan masalah tersebut adalah scientific approach (pendekatan ilmiah).

Berdasarkan latar belakang di atas, maka dapat dirumuskan masalah Bagaimanakah penerapan Scientific Approach dalam pembelajaran Matematika materi Jaringjaring Bangun Ruang siswa kelas V semester 2 di SDN 6 Dawuhan Situbondo Tahun ajaran 2013/2014? Apakah penerapan Scientific Approach bisa meningkatkan berpikir kritis siswa kelas $\mathrm{V}$ dalam pembelajaran matematika materi Jaring-jaring Bangun Ruang semester 2 di SDN 6 Dawuhan Situbondo

Tahun ajaran 2013/2014 ? Apakah penerapan Scientific Approach bisa meningkatkan hasil belajar siswa kelas V dalam pembelajaran matematika materi Jaring-jaring 
Bangun Ruang semester 2 di SDN 6 Dawuhan Situbondo Tahun ajaran 2013/2014?

Tujuan penelitian ini adalah mendeskripsikan penerapan Scientific Approachdalam pembelajaran Matematika materi jaring-jaring bangun ruang siswa kelas Kelas V semester 2 di SDN 6 Dawuhan Situbondo tahun pelajaran 2013/2014, mengetahui peningkatan kemampuan berpikir kritis siswa melalui penerapan Scientific Approach dalam pembelajaran Matematika materi jaring-jaring Bangun Ruang siswa kelas Kelas V semester 2 di SDN 6 Dawuhan Situbondo Tahun ajaran 2013/2014, mengetahui peningkatan kemampuan hasil belajar siswa melalui penerapan Scientific Approach dalam pembelajaran Matematika materi Jaring-jaring Bangun Ruang siswa kelas Kelas V semester 2 di SDN 6 Dawuhan Situbondo Tahun ajaran 2013/2014.

Matematika sekolah merupakan pelajaran matematika yang diberikan di jenjang pendidikan menengah ke bawah Erman Suherman menyatakan Fungsi mata pelajaran matematika di sekolah antara lain sebagai alat untuk memahami dan menyampaikan informasi, pembentukan pola pikir, serta sebagai ilmu pengetahuan [1]

Kemampuan berpikir kritis yang dimiliki siswa sangat membantu dalam menentukan informasi yang penting didapatkan, diubah, ditransformasikan, dan dipertahankan.

Pembelajaran dengan Scientific Approach adalah proses pembelajaran yang dirancang sedemikian rupa agar peserta didik secara aktif mengonstruk konsep, hukum atau prinsip melalui tahapan-tahapan mengamati (untuk mengidentifikasi atau menemukan masalah), merumuskan masalah, mengajukan atau merumuskan hipotesis, mengumpulkan data dengan berbagai teknik, menganalisis data, menarik kesimpulan dan mengomunikasikan konsep, hukum atau prinsip yang "ditemukan".

Pembelajaran dengan scientific approach adalah proses pembelajaran yang dirancang sedemikian rupa agar peserta didik secara aktif mengonstruk konsep, hukum atau prinsip melalui tahapan- tahapan mengamati (untuk mengidentifikasi atau menemukan masalah), merumuskan masalah, mengajukan atau merumuskan hipotesis, mengumpulkan data dengan berbagai teknik, menganalisis data, menarik kesimpulan dan mengomunikasikan konsep, hukum atau prinsip yang "ditemukan".

\section{METODE}

Tempat penelitian ada di SDN 6 Dawuhan Situbondo. Waktu penelitian dilakukan pada 25 april sampai dengan 23 Mei 2014. Subyek dalam penelitian tindakan kelas ini adalah guru SDN 6 Dawuhan Situbondo. Sedangkan objek dalam penelitian tindakan kelas ini adalah siswa kelas V SDN 6 Dawuhan Situbondo. Definisi operasional dalam penelitian ini adalah Pembelajaran Scientific Approach yaitu Aktivitas guru dan respon siswa diukur berdasarkan lembar observasi aktivitas guru dan lembar observasi respon siswa. Berfikir kritis diukur berdasarkan observasi berpikir kritis dalam kelompok dan dari kuis individu sesuai indikator ompetensi yang terdiri dari 5 soal essai setiap siklus. Hasil belajar siswa diukur berdasarkan nilai ulangan harian sesuai dengan indikator kompetensi yang terdiri dari 10 essai setiap siklus.

Metode yang digunakan dalah Penelitian Tindakan Kelas (PTK) atau sering disebut dengan Classroom Action Research. Pelaksanaan penelitian dilaksanakan dengan cara kolaborasi yang melibatkan guru kelas V dan peneliti sebagai observer dan alur tahapan (perencanaan, tindakan, observasi, dan refleksi disajikan dalam dua siklus). Prosedur penelitian Tahap Perencanaan Tahap Pelaksanaan Tahap observasi Refleksi. Teknik yang digunakan untuk mengumpulkan data dalam penelitian ini adalah: (1) Teknik Observasi; (2) Teknik wawancara; (3) Teknik Tes; (4) Teknik Dokumentasi. Data yang diperoleh dalam penelitian ini dianalisis dengan menggunakan model analisis deskriptif persentase. Peneliti menghitung efektivitas penerapan pembelajaran Scientific Approach, digunakan persentase keaktifan guru $(\mathrm{Pi})$ dengan rumus:

Data hasil kuis dianalisis dengan menghitung hasil berpikir matematika setelah penerapan pembelajaran Scientific Approach dapat dilakukan dengan rumus:

$$
P_{b}=\frac{b}{B} \times 100 \%
$$

Keterangan :

$\mathrm{Pb}$ : persentase peningkatan berpikir kritis siswa b: jumlah siswa yang mengalami peningkatan

berpikir kritis

B: jumlah seluruh siswa

Data hasil ulangan harian dianalisis dengan menghitung hasil belajar matematika setelah penerapan pembelajaran Scientific Approach dapat dilakukan dengan rumus:

$$
P_{t}=\frac{n}{N} \times 100 \%
$$

Keterangan:

$\mathrm{Pt}$ : persentase peningkatan hasil belajar siswa

$\mathrm{n}$ : jumlah siswa yang mengalami ketuntasan belajar

$\mathrm{N}$ : jumlah seluruh siswa

\section{HASIL DAN PEMBAHASAN}

HASIL

Berdasarkan hasil observasi aktivitas guru, dapat diketahui bahwa persentase rata-rata aktivitas guru pada siklus 1 (pertemuan 1 dan 2) aktif. Aktivitas guru meningkat dari pertemuan 1 dan 2 dan termasuk dalam kriteria aktif.

Hasil wawancara siswa kelas V,pembelajaran matematika dengan Scientific Approach menyenangkandan memudahkan siswa dalam belajar. Sedangkan, hasil wawancara dengan guru menunjukkan bahwa pembelajaran yang dilakukan guru cukup lancar. Diperoleh hasil persentase analisis berpikir kritis siswa pada siklus 1 seperti pada gambar 1 . 


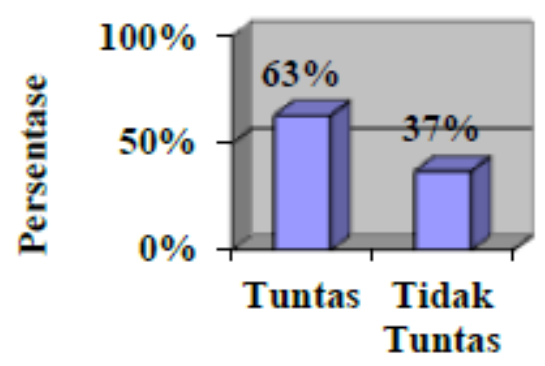

Jumlah Siswa

Gambar. 1 Grafik persentase berpikir kritis siklus 1

Berdasarkan hasil observasi, wawancara dan ulangan harian pada siklus 1 diketahui bahwa hasil belajar siswa mengalami peningkatan dibandingkan sebelum tindakan menggunakan Scientific Approach. Scientific Approach yang belum maksimal. Persentase hasil belajar siswa pada siklus 1 , seperti pada gambar 2 .

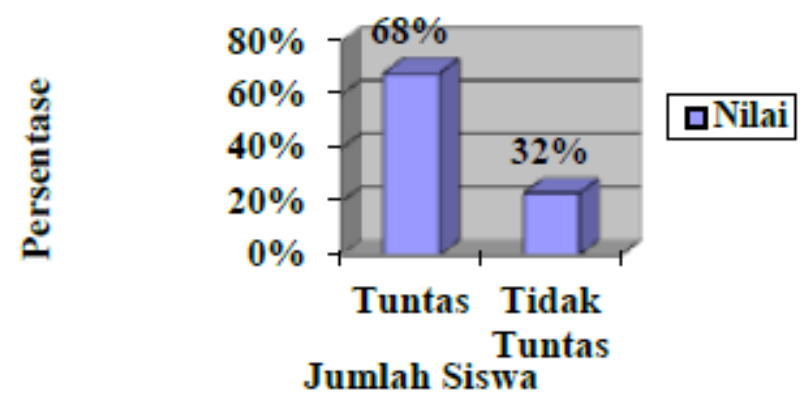

Gambar. 2 Grafik persentase hasil belajar siklus 1

Grafik tersebut menunjukkan bahwa ketuntasan hasil belajar siswa sudah meningkat dan lebih baik dibanding hasil pre test yang sebelumnya. Berdasarkan analisis hasil observasi, wawancara dan ulangan harian dapat disimpulkan bahwa pelaksanaan siklus 1 dalam upaya meningkatkan hasil belajar siswa kelas V sudah mengalami peningkatan.

Hasil observasi aktivitas guru pada siklus 2 dapat diketahui bahwa persentase rata-rata aktivitas guru pada siklus 2 (pertemuan 1 dan 2) sangat aktif. Aktivitas guru meningkat dari pertemuan 1 dan 2 .

Pada siklus 2 sudah terlihat pola berpikir siswa seperti pada gambar 3 .

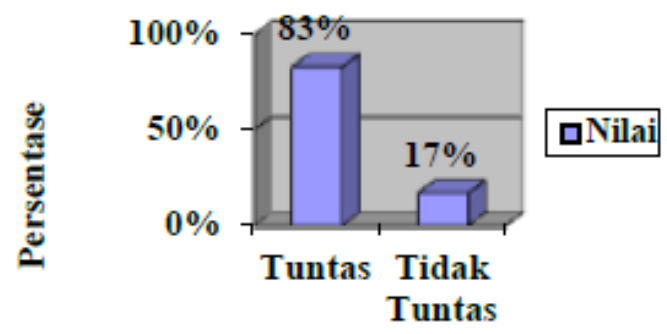

Jumlah Siswa

Gambar. 3 Grafik persentase berpikir kritis siklus 2
Berdasarkan gambar 3, persentase berpikir kritis siswa pada pelajaran matematika kelas $\mathrm{V}$ pada siklus 2 menunjukkan bahwa ketuntasan berpikir kritis siswa sudah meningkat dan lebih baik dibanding siklus 1, siswa lebih berani berargumen, merumuskan masalah, melakukan deduksi, induksi, evaluasi, menuntaskan dan melaksanakan di dalam kelompok maupun mengerjakan kuis.

Berdasarkan hasil analisis hasil belajar siswa, diperoleh hasil persentase analisis hasil belajar siswa pada siklus 2, seperti pada gambar 4.

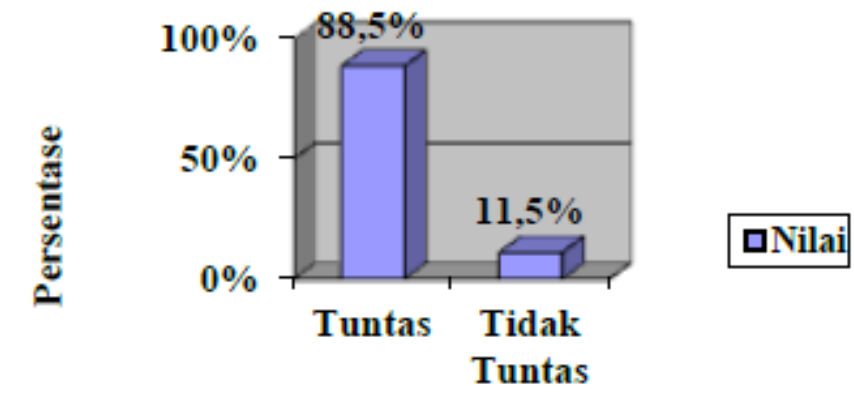

Jumlah Siswa

Gambar. 4 Grafik persentase hasil belajar siklus 2

Berdasarkan gambar 4persentase hasil belajar matematika kelas $\mathrm{V}$ pada siklus 2 menunjukkan bahwa ketuntasan hasil belajar siswa sudah meningkat dan lebih baik dibanding hasil siklus 1 . Siswa yang mengalami ketuntasan belajar mencapai 31 siswa, sedangkan yang tidak tuntas mencapai 4 siswa. Berdasarkan analisis hasil observasi, wawancara dan ulangan harian dapat disimpulkan bahwa pelaksanaan siklus 2 dalam upaya meningkatkan hasil belajar siswa kelas $\mathrm{V}$ sudah mengalami peningkatan yakni $88,5 \%$.

Penelitian ini telah menjawab rumusan masalah yang dikemukakan oleh peneliti. Yang pertama yaitu Langkahlangkah penerapan pembelajaran Scientific Approach yaitu guru melakukan apersepsi, membentuk kelompok. menyajikan materi, memberikan kesempatan bertanya kepada siswa, memberikan masalah untuk dipecahkan siswa, siswa mengumpulkan informasi, siswa mengolah informasi tersebut dan mempersentasikannya didepan kelas. Yang kedua yaitu Penerapan pembelajaran Scientific Approach bisa meningkatkan berpikir kritis siswa dan hasil belajar siswa kelas $\mathrm{V}$ pada materi jaring-jaring bangun ruang. Berdasarkan hasil analisis data, diperoleh data bahwa siklus 1 mencapai $63 \%$ yaitu sebanyak 22 siswa yang mangalami ketuntasan dalam mengerjakan kuis. Pada siklus 2, berpikir kritis siswa mengalami peningkatan menjadi $83 \%$ yaitu sebanyak 29 siswa mangalami ketuntasan dalam mengerjakan kuis. Peningkatan berpikir kritis dari siklus 1 ke siklus 2 sebesar 20\%. Selain itu diperoleh data bahwa sebelum penerapan Scientific Approach persentase hasil belajar siswa mencapai $45 \%$ yaitu sebanyak 16 siswa mencapai ketuntasan belajar dalam pre tes. Persentase hasil belajar siswa pada siklus 1 mencapai $68 \%$ yaitu sebanyak 24 siswa yang mengalami ketuntasan belajar dalam ulangan harian. Pada siklus 2, hasil belajar siswa mengalami 
peningkatan menjadi $88,5 \%$ sebanyak 31 siswa yang mengalami ketuntasan belajar dalam ulangan harian. Peningkatan hasil belajar dari pre tes ke siklus 1 sebesar 23\%. Peningkatan hasil belajar dari siklus 1 ke siklus 2 sebesar 20,

\section{KESIMPULAN}

Berdasarkan hasil penelitian, analisis data, dan pembahasan dapat disimpulkan yang pertama yaitu pembelajaran scientific approach diterapkan dengan cara: (1) menyampaikan kompetensi yang akan dicapai, (2) menyajikan materi, (3) memberikan kesempatan bertanya, (4) membentuk tim dengan anggota 5-6 siswa untuk mengerjakan lembar kerja siswa, (4) mencari informasi,(5) mengolah informasi, (6) menarik kesimpulan, (7) mengkomunikasikan dan (8) mengerjakan kuis. Yang kedua Penerapan pembelajaran scientific approach bisa meningkatkan berpikir kritis. Yang ketiga yaitu Penerapan pembelajaran scientific approach bisa meningkatkan hasil belajar siswa.

\section{DAFTAR PUSTAKA}

[1] Apriyani. 2010. "Penerapan Model Learning Cycle "5e" Dalam Upaya Meningkatkan Kemampuan Pemecahan Masalah Matematika Siswa SMPN 2 Sanden Kelas Viii Pada Pokok Bahasan Prisma Dan Limas". Tidak diterbitkan. Skripsi. Yogyakarta: Universitas Negeri Yogyakarta.

[2] Fety. 2011. "Upaya Meningkatkan Kemampuan Berpikir Kritis Dan Kreatif Siswa Kelas X Administrasi Perkantoran (Ap) Smk Negeri 1 Depok Pada Pembelajaran Matematika Dengan Metode Problem Posing Tipe Presolution Posing". Tidak diterbitkan. Skripsi. Yogyakarta: Universitas Negeri Yogyakarta.

[3] Fachrurazi.2011 ."Penerapan Pembelajaran Berbasis Masala Untuk Meningkatkan Kemampuan Berpikir Kritis Dan Komunikasi Matematis Siswa Sekolah Dasar". Jurnal. Diakses pada tanggal 2 Januari 2014. Http: //Jurnal.Upi.Edu/File/8 -Fachrurazi.Pdf
[4] Hariyanti. 2010. " Upaya Meningkatkan Kemampuan Penalaran Matematika Siswa Kelas Vii C Smp Negeri 2 Depok Sleman Dalam Pembelajaran Matematika Melalui Pendekatan Investigasi". Tidak diterbitkan. Skripsi. Yogyakarta: Universitas Negeri Yogyakarta.

[5] Kemendikbud. 2013. "Kurikulum 2013 Kompetensi Dasar Sd". Diakses pada tanggal 4 Januari 2014. Http://Www.PendidikanDiy.Go.Id/File/Mendiknas/Kurik ulum-2013 -Kompetensi-Dasar-SdVer-3-3-2013.Pdf

[6] Putu. 2011. "Pengaruh Lingkungan Sekitar Sebai Media Pembelajaran IPA dan Motivasi BerprestasiTerhadap Kemampuan Berfikir Kritis Siswa SD Kelas V Gugus IV Gerokdak". Tidak diterbitkan. Tesis. Bali: PPS UNDIKSA.

[7] Rosnawati. 2012. "Berpikir Kritis Melalui Pembelajaran Matematika Untuk Mendukung Pembentukan Karakter Siswa". Jurnal. Diakses pada tanggal 2 Januari 2014. Http://Staff.Uny.Ac.Id/Sites/Def ault/Files/Penelitian/R.\%20rosna wati,\%20dra.\%20m.Si./Makalah An Rosnawati Uny 29 Juni 2012 Apload.Pdf

[8] Rahmita. 2013. "Penerapan Pendekatan Scientific Dalam Pembelajaran Matematika Smp Kelas Vii Materi Bilangan (Pecahan)". Http://Eprints.Uny.Ac.Id/10777/ 1/P\%20-\%2054.Pdf Sugiyanto. 2013. "Pendekatan Saintifik". Jurnal. Diakses pada tanggal 2 Januari2014. Http://Www.Academia.Edu/521 9050/Uraian_Materi_Pendekatan And Startegi Pembelajaran

[9] Sitiatava. 2013. "Desain belajar mengajar kreatif berbasis sains". Jogjakarta: DIVA Pres

[10] Tanti. 2012. "Kompetensi Berpikir Kritis Dan Kreatif Dalam Pemecahan Masalah Matematika Di SmpNegeri 2 Malang". Jurnal. Diakses pada tanggal 2 Januari 2014. Http://Ejournal.Umm .Ac. Id/Index.Php/Pen math/Article/Viewfile/612/634_Umm_Scie ntific_Journal.Pdf 